\title{
Lemmel's Syndrome: A Rare Cause of Obstructive Jaundice/Cholangitis/Pancreatitis
}

\author{
Mandeep Kaur* and Chintamani \\ Safdarjang Hospital, India
}

Submission: February 10, 2017; Published: April 26, 2017

*Corresponding author: Mandeep Kaur, Safdarjang Hospital, Ring Road, Opposite AIIMS Hospital, Safdarjung West, Safdarjung Campus, Ansari

Nagar East, New Delhi, Delhi 110029, India, Email: sandhu.mandeep02@googlemail.com

\section{Clinical Image}

Lemmel's syndrome, first described by Lemmel in 1934, refers to duodenal diverticulum of second part of duodenum compressing on the Common bile duct which may present as obstructive jaundice, cholangitis, pancreatitis, or intrahepatic/ cholangiolar abscess.

50 Years old lady presented to our unit with chief complaints of pain epigastric region and deranged liver profile. A clinical diagnosis of pancreatitis was made and the patient managed accordingly. Subsequently CECT abdomen (Figure 1 \& 2) was done which showed diverticula of second part of duodenum compressing on the intrapancreatic portion of $\mathrm{CBD}$, dilatation of suprapancreatic portion of CBD, cholangiolar abscess. Barium swallow (Figure 3) of the patient also showed diverticula of second part of duodenum. Side viewing endoscopy confirmed the diagnosis Lemmel's syndrome $[1,2]$.

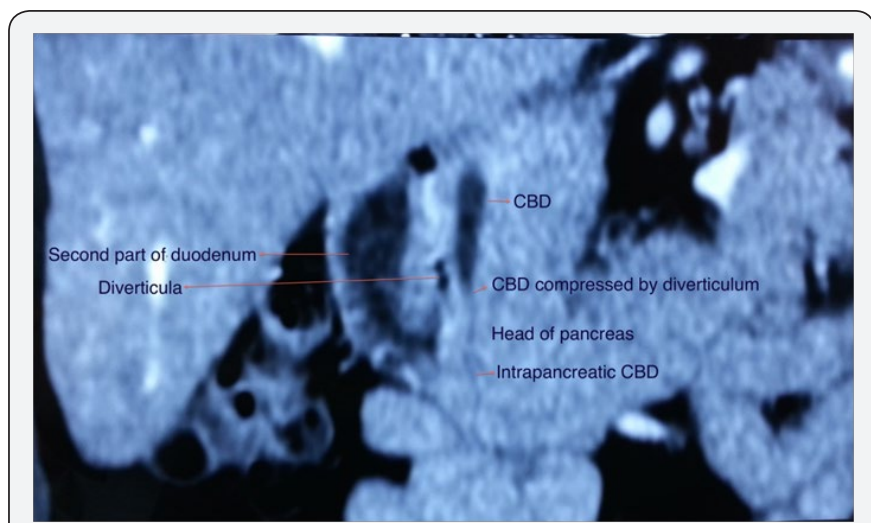

Figure 1: CECT abdomen showing the findings as described in the image.
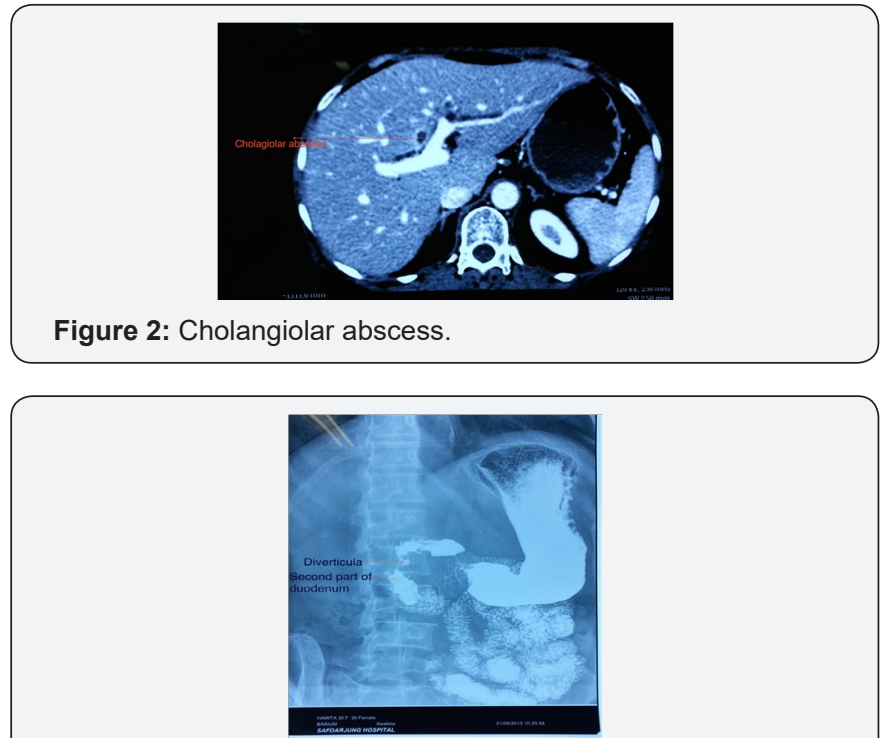

Figure 3: Barium Swallow showing diverticula of second part of diverticulum

ERCP and sphincterotomy relieved the patient of all the symptoms.

\section{References}

1. Kang HS, Hyun JJ, Kim SY, Jung SW, Koo JS, et al. (2014) Lemmel's Syndrome, an Unusual Cause of Abdominal Pain and Jaundice by Impacted Intradiverticular Enterolith: Case Report. Journal of Korean Medical Science 29(6): 874-878.

2. Karayiannakis AJ, Bolanaki H, Courcoutsakis N, Kouklakis G, Moustafa E, et al. (2012) Common Bile Duct Obstruction Secondary to a Periampullary Diverticulum. Case Reports in Gastroenterology 6(2): 523-529. 


\section{Your next submission with Juniper Publishers} will reach you the below assets

- Quality Editorial service

- Swift Peer Review

- Reprints availability

- E-prints Service

- Manuscript Podcast for convenient understanding

- Global attainment for your research

- Manuscript accessibility in different formats

( Pdf, E-pub, Full Text, Audio)

- Unceasing customer service

Track the below URL for one-step submission https://juniperpublishers.com/online-submission.php 